\title{
A Review of Sea Cucumber Aquaculture, Ranching, and Stock Enhancement in China
}

\section{Qingxi Han, John K. Keesing \& Dongyan Liu}

To cite this article: Qingxi Han, John K. Keesing \& Dongyan Liu (2016) A Review of Sea Cucumber Aquaculture, Ranching, and Stock Enhancement in China, Reviews in Fisheries Science \& Aquaculture, 24:4, 326-341, DOI: 10.1080/23308249.2016.1193472

To link to this article: http://dx.doi.org/10.1080/23308249.2016.1193472

\section{Published online: 21 Jun 2016.}

\section{Submit your article to this journal $\square$}

Џ Article views: 115

Q View related articles $\square$

View Crossmark data ¿

印

Citing articles: 2 View citing articles $\sqsubset$ 


\title{
A Review of Sea Cucumber Aquaculture, Ranching, and Stock Enhancement in China
}

\author{
Qingxi Han ${ }^{a, b}$, John K. Keesing ${ }^{c}$, and Dongyan Liu ${ }^{b}$

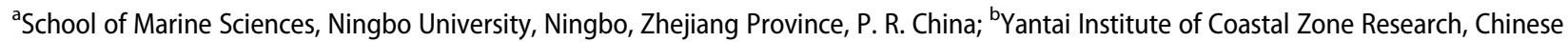 \\ Academy of Sciences, Yantai, Shandong, P. R. China; 'CSIRO Oceans and Atmosphere Research, Wembley, Australia
}

\begin{abstract}
Sea cucumber aquaculture has flourished as a result of increasing demand coupled with declining wild fisheries and has been facilitated by technical progress in the production and grow-out phase of larvae and small juvenile sea cucumbers. China has developed a large and successful sea cucumber aquaculture industry based on the temperate species Apostichopus japonicus (Selenka, 1867). China consumes most of its domestic sea cucumber production (193, 705 tons: 2013), exporting only a few dozen tons. Much of the success of sea cucumber aquaculture in China came from advances in culture methods, especially for the early stages of broodstock conditioning, larval production and settlement, and the critical early juvenile development stage. These artificial approaches to production are a precondition for all aquaculture models, and the scientific procedures and management protocols must be strictly adhered to for success. Similarly, the growout phase of sea cucumber production in China has evolved from attempts using disused fish and shrimp ponds to new, dedicated ponds developed to meet the more sensitive requirements of sea cucumbers for water quality and substrate type and to the use of ocean ranching. Various diseases have affected this industry and become barriers to its sustainable development. To achieve higher survival rates and better production quality, the trend has been toward ocean ranching of sea cucumbers and stock enhancement, and production levels have increased significantly in recent years. While cost-effective methods for sea cucumber aquaculture close to their point of consumption is good news for wild stocks of sea cucumbers in different parts of the world, there is a potential downside in the environmental impact of such extensive production methods. The influence of sea cucumber aquaculture on the environment and the influence of the environment on sea cucumber aquaculture are important issues relating to ecological security and sustainability.
\end{abstract}

\section{KEYWORDS}

Sea cucumber; Apostichopus japonicas; stock enhancement; China; sea ranching

\section{Introduction}

As a famous tonic and traditional medicine, sea cucumber is popular in China and other Asian countries deeply influenced by Chinese traditional culture, e.g., Korea, Japan, Vietnam, and Singapore, where sea cucumbers are consumed as a delicacy, an aphrodisiac, or a natural medicine (Liao, 1997; Yu et al., 2010). Eating sea cucumber is strongly entrenched in Chinese custom, especially in coastal areas. This history can be traced back to the Ming Dynasty (1368-1644 AD) (Chen, 2003).

The oldest undisputed fossil evidence of sea cucumbers dates from the late Silurian period approximately 400 million years ago (Gilliland, 1993), with another controversial record from approximately 460 million years (Botting and Muir, 2012; Smith et al., 2013). Over 1,400 sea cucumber (Echinodermata: Eleutherozoa: Holothuroidea) species belonging to 160 genera are described worldwide (Smiley et al., 1994). In the People's
Republic of China (hereafter China), 134 species have been recognized belonging to 57 genera, 15 classes, and 6 orders (Liao, 1997). Most species are distributed south of Hainan Island, while the most economically valuable species (Apostichopus japonicus, Selenka, 1867) is distributed in northern China.

The sea cucumber A. japonicus has become an important aquaculture species in China and Japan (Chen, 2004). The species is widely distributed in northern China (north of Lianyungang City, Jiangsu Province, $34.5^{\circ} \mathrm{N}$ ), Japan, the Korean Peninsula, and Far East Russia (Liao, 1997). A. japonicus belongs to Stichopodidae (Family) and Aspidochirotida (Order). Synonymized taxa are: Holothuria armata Selenka, 1867; Stichopus japonicus Selenka, 1867, Stichopus japonicus var. typicus Théel, 1886, Stichopus roseus Augustin, 1908.

Sea cucumber fisheries have developed in many parts of the world, and most have declined as a result of 
overfishing (Conand, 2004; Uthicke, 2004). The decline in wild fisheries coupled with an increased demand, particularly for high-quality sea cucumber species, resulted in a rapid expansion in aquaculture, especially in China. Although Purcell et al. (2012) recently reviewed developments in the aquaculture of tropical sea cucumbers, the last review of sea cucumber aquaculture that covered developments in China was "Advances in sea cucumber aquaculture and management" published in 2004 (Lovatelli et al., 2004). This information is now dated, and an up-to-date review is warranted given the increased demand for sea cucumber products and the expansion of sea cucumber aquaculture, particularly in China, where a large body of sometimes-inaccessible literature on the topic exists. Here, we cover those literature sources, as well as reviewing all aspects of sea cucumber aquaculture with a focus and emphasis on China.

The number of commercially exploited species varies widely, with the highest number of species in the Asia (52 species) and Pacific (36 species) regions, partially due to the higher natural diversity in these areas. The majority of sea cucumbers are exported for the bêche-de-mer market, with a few species for the live trade (aquarium) market (Toral-Granda et al., 2008). Sea cucumbers Parastichopus californicus and A. japonicus are the most abundant edible species in the temperate Pacific. Most commercially important sea cucumbers are distributed in tropical oceans, accounting for $86 \%$ of the total production (Wang et al., 1998). High-value species have been depleted, and previously unfished species are now exploited.

The FAO database (FishstatJ version 2.12.2) lists the three major Chinese import markets for sea cucumbers (mainland China, Hong Kong, and Taiwan) as accounting for $82.3 \%$ of global import quantity and $90.8 \%$ of global import value, including dried, salted or in brine, frozen, live, fresh or chilled, prepared or preserved sea cucumber. This value totaled 11,199 tons in quantity and US\$ 433,457 million in value in 2011. Hong Kong was the leading importer of sea cucumber, accounting for $51.8 \%$ of total imports in quantity and $85.4 \%$ in value worldwide, but a major proportion of the sea cucumber imported into Hong Kong in all forms was re-exported to other parts of China and other countries. However, China consumes much more sea cucumber than the import quantity suggests because of its massive domestic production, including more than 200,969 fresh tons of sea cucumbers in 2014 (China Fisheries Yearbook, 2015).

Since the 1980s, elevated export prices and huge demand from those Asian markets influenced by Chinese culture and diet have been the catalysts for increased fishing (Kinch et al., 2008). However, sea cucumbers are vulnerable to overexploitation by fishing because of their biological behavior, population dynamics, and habitat preferences, such as late maturity, density-dependent reproduction, and low rates of recruitment (Bruckner et al., 2003). Sea cucumber fisheries in most countries have experienced boom-and-bust cycles since the late nineteenth century (Kinch et al., 2008). The exception is China, which has produced most of its domestic sea cucumber production by mariculture since the late 1980s. However, there have been advances in rehabilitation programs for sea cucumber populations affected by overfishing. One solution is stock enhancement, which involves raising juveniles in hatcheries and releasing them into the wild (Shiell, 2004). Ocean ranching, a form of stock enhancement, has also become popular in China.

\section{Sea cucumber aquaculture}

\section{Development of sea cucumber aquaculture}

Although there are many species available in bêchede-mer markets, the temperate species A. japonicas is the most extensively cultivated species in northern China, Japan, and Korea. Attempts have also been made to culture A. japonicus in southern China during the winter to obtain a higher growth rate. In this review, we outline the important factors that have enabled aquaculture practice, as well as the challenges confronted and the opportunities provided, by drawing on an extensive literature, much of which is published in Chinese and is thus of limited access to researchers outside China.

\section{Profile of sea cucumber aquaculture in China}

The output of both the capture (fishery) and aquaculture sectors grew steadily before 1998 . The capture output was then surpassed by that of aquaculture, which increased rapidly from 1998 to 2002. Table 1 shows a dramatic increase in sea cucumber output from 5,865 metric tons in 2002 to 38,952 metric tons in 2003. Since 2003, when the capture output all but ceased, aquaculture production has dominated the yield (Table 1). Because of rapid development and lack of standardization in husbandry methods, sea cucumber aquaculture ventures suffered huge economic losses due to diseases and mass mortalities (Wang et al., 2004). As the biggest sea cucumber producers, the northeastern provinces of Liaoning and Shandong have supplied $85-95 \%$ of the sea cucumbers (A. japonicus) since 1990. In 2013, Shandong and Liaoning constituted 49.8 and $36.5 \%$ of the total national production, respectively, (Table 1). The sea cucumber production of Fujian (a southern province in China, adjacent to Taiwan and across the Taiwan Strait) has been recorded since 2005, and it has recently become an important sea cucumber supplier, accounting for $9.1 \%$ of total national production in 2013 (Table 1). Pond aquaculture, 
Table 1. Annual production of sea cucumber in China by province, fresh weight, 1989-2014 (China Bureau of Fisheries, 1990-2015).

\begin{tabular}{|c|c|c|c|c|c|c|c|c|c|c|}
\hline & \multicolumn{2}{|c|}{ Shandong P. } & \multicolumn{2}{|c|}{ Liaoning $\mathrm{P}$. } & \multicolumn{2}{|c|}{ Fujian P } & \multicolumn{2}{|c|}{ Hebei P. } & \multicolumn{2}{|c|}{ National total } \\
\hline & Culture $(t)$ & Capture $(t)$ & Culture $(t)$ & Capture $(t)$ & Culture $(t)$ & Capture $(t)$ & Culture $(t)$ & Capture $(t)$ & Culture $(t)$ & Capture $(t)$ \\
\hline 1989 & 12.975 & 7.95 & - & 69 & - & - & - & - & 12.975 & 101.92 \\
\hline 1990 & 0.15 & 16.478 & - & 87.5 & - & - & - & - & 0.15 & 135.608 \\
\hline 1991 & 1.77 & 19.436 & - & 99.5 & - & - & - & - & 1.77 & 143.171 \\
\hline 1992 & 5.22 & 83.565 & - & 167 & - & - & - & - & 5.22 & 264.365 \\
\hline 1993 & 45 & 55.885 & - & 293 & - & 1.01 & - & - & 45 & 362.805 \\
\hline 1994 & 170 & 355.86 & - & 350 & - & 0.008 & - & - & 170.045 & 706.823 \\
\hline 1995 & 128.03 & 444.08 & 179 & 165 & - & 0.148 & - & - & 307.03 & 616.128 \\
\hline 1996 & 814.85 & 379.489 & - & 895 & - & - & - & - & 814.85 & 1282.489 \\
\hline 1997 & 424.3 & 330 & 599 & 1016 & - & - & - & - & 1023.3 & 1352 \\
\hline 1998 & 396.4 & 476 & 945 & 971 & - & 15.04 & - & - & 1341.4 & 1467.04 \\
\hline 1999 & 479 & 160 & 50 & 146 & - & 1.817 & 1 & - & 530 & 308.817 \\
\hline 2000 & 821.001 & 40 & 2485 & 584 & - & 15 & - & - & 3307.001 & 645.714 \\
\hline 2001 & 1253 & 102 & 3837 & 230 & - & 14 & 1 & - & 5091 & 358.44 \\
\hline 2002 & 1844.3 & 46 & 4021 & 390 & - & 28 & - & - & 5865.3 & 470.232 \\
\hline 2003 & 29961 & - & 7185 & - & 1 & - & - & - & 38952 & - \\
\hline 2004 & 40370 & - & 11529 & - & - & - & 33 & - & 53315 & - \\
\hline 2005 & 46017 & - & 16157 & - & 238 & - & 209 & - & 65283 & - \\
\hline 2006 & 53080 & - & 21236 & - & 324 & - & 1064 & - & 75725 & - \\
\hline 2007 & 53572 & - & 22158 & - & 651 & - & 515 & - & 77517 & - \\
\hline 2008 & 60689 & - & 29034 & - & 1224 & - & 1183 & - & 92567 & - \\
\hline 2009 & 62792 & - & 36134 & - & 1338 & - & 1508 & - & 102159 & - \\
\hline 2010 & 66300 & - & 59764 & - & 1643 & - & 2128 & - & 130303 & - \\
\hline 2011 & 71011 & - & 54954 & - & 7082 & - & 4024 & - & 137754 & - \\
\hline 2012 & 82905 & - & 64512 & - & 15459 & - & 6649 & - & 170830 & - \\
\hline 2013 & 96523 & - & 70,687 & - & 17,555 & - & 7976 & - & 193705 & - \\
\hline 2014 & 99560 & - & 68754 & - & 22227 & - & 12145 & - & 200969 & - \\
\hline
\end{tabular}

sea ranching, and restocking are the main methods used in Liaoning and Shandong, while raft aquaculture, which can produce a higher yield is employed in Fujian province (Han et al., 2011; Liu and You, 2013; Yu, 2013; Table 1).

Driven by the recent high profits from sea cucumber, some southern farmers (mostly Fujian Province) purchased sea cucumber juveniles (A. japonicus) from Shandong and Liaoning in October and cultured the sea cucumbers in the warmer southern waters to encourage higher growth rates; however, they must sell the sea cucumber before March and April of the next year, as sea cucumbers cannot endure the high temperature of low-latitude oceans in summer. In 2013, Fujian harvested 17,555 metric tons of fresh sea cucumber (Table 1) which flooded the market from March to April causing a $15 \%$ collapse in prices.

By the end of 2003, over 20,000 ha of disused shrimp ponds and newly built ponds were adopted for the aquaculture of A. japonicus, especially in eastern Shandong and southern Liaoning. As the largest sea cucumber producer, Shandong province supplied over 99,560 tons in 2014 , with an average annual compound growth of $11.5 \%$ during 2003-2014.

\section{Larval culture methods for sea cucumbers}

The development of $A$. japonicus aquaculture has been enabled by breakthroughs in artificial breeding. Artificial fertilization and stock enhancement in Japan can be traced back to the 1930s (Sui, 1990; Yu et al., 2010). In China, artificial breeding dates back to the 1950s, but the optimum temperature for sea cucumber spawning was not established until the late 1970s (Zhang and Liu, 1998; Yu et al., 2010). In the 1980s, the shortage of sea cucumber juveniles was a bottleneck for developing aquaculture. Sea cucumber farming extended rapidly in northern China after the development of hatcheries and juvenile production (Chen, 2003; Chang and Chen, 2008). Pond and tank aquaculture were adopted first, followed by sea ranching. Stock enhancement became increasingly popular due to the demand for high-quality sea cucumber. As explained above, there have been attempts to culture A. japonicus in southern areas in winter, e.g., Fujian, Guangxi, and Zhejiang provinces (Yu, 2013) where they must be harvested before aestivation occurs (sea cucumber cease feeding and growth when temperature is higher than $20^{\circ} \mathrm{C}$ ). However, all these aquaculture models require the supplement of juvenile sea cucumbers from the more northern Shandong and Liaoning provinces (Liu and You, 2013; Yu, 2013).

The process of artificial reproduction of juvenile seedstock includes broodstock collection and maintenance, spawning, larval development, and nursery of juveniles. These stages are discussed in detail.

\section{Broodstock}

A. japonicus broodstock are collected in late May to early July, when they reach sexual maturity as the water near the seabed reaches $15-17^{\circ} \mathrm{C}$ (Zhang and Liu, 1998; Xie, 2004; Chang and Chen, 2008; Ke, 
2010; Yu et al., 2010). Sea cucumbers are collected when the mature individuals are two years old, weigh approximately $250 \mathrm{~g}$, and contain gonads comprising over $10 \%$ of the total body weight (Zhang and Liu, 1998; Xie, 2004; Ke, 2010; Yu et al., 2010). Individuals with larger body weight and higher relative gonad weight will perform better as broodstock. The females spawn after a period of domestication to adapt the changed living conditions. Injured or derma-damaged individuals must not be used as broodstock. The water temperature should be increased after three days of broodstock domestication and should be maintained at $16-18^{\circ} \mathrm{C}$ for $7-10$ days before spawning is induced. To enhance broodstock activity, aeration should run continuously. Water exchange, cleaning, and removal of damaged individuals should occur daily. Sea cucumbers are fed by artificial diets based on Zostera marina, Sargassum thunbergia, copepod, and diatoms (Luan et al., 2006). Spawning occurs soon after the broodstock move frequently or shake their anterior body sections to the left and right (Zhang and Liu, 1998).

\section{Spawning and fertilization}

After gonad maturation, the sea cucumber spawns between sunset and 20:00-21:00 at a water temperature of $18-23^{\circ} \mathrm{C}$. Methods to achieve manual spawning include thermal shock and desiccation. Thermal shock is achieved by raising the water temperature by $3-5^{\circ} \mathrm{C}$, and then broodstock will begin spawning (Chang and Chen, 2008; Yu et al., 2010). The desiccation followed by seawater jet method is achieved by air exposure and seawater stimulation. First, the pond is drained, and the broodstock are exposed to air for $0.5-1 \mathrm{hr}$. The broodstock are then washed with slowly flowing water for approximately 40-50 min. Finally, the pool is refilled with fresh seawater (Chang and Chen, 2008; Yu et al., 2010). Generally, sperm release by males occurs $0.5 \mathrm{hr}$ after spawning by females (Xie, 2004). It is important to control the egg density below one million eggs per $\mathrm{m}^{3}$ in hatchery tanks (Chang and Chen, 2008).

Embryonic development begins after fertilization when the diameter of the oocyte is approximately 120 $130 \mu \mathrm{m}$ (Chen, 2003). Management must be carried out very carefully during the embryonic development and larval growth phases. The water temperature should be sustained at $18-23^{\circ} \mathrm{C}$, and the density should be approximately $10-20 \mathrm{ml}^{-1}$ (Luan et al., 2006). Water agitation should occur every half hour to avoid the deposition of eggs and embryos to the bottom of the tanks during the gastrulation period.

\section{Larval development, settlement, and metamorphosis}

The larvae proceed through the gastrula, auricularia, doliolaria, pentactula, and finally juvenile stages after spawning and fertilization. The highest mortalities occur during the auricularia stage and the 7-10 day old juvenile stage due to digestive duct diseases (Chen, 2003). To increase the survival rate, it is essential to provide the appropriate diet and to follow sophisticated routine management. The pre-auricularia larvae begin to feed on unicellular algae, including Dunaliella salina, Phaeodactylum tricornutum, and Chaetoceros simplex, marine yeast, and a mixture of diatom and chrysophyceae (Chen, 2003; Xie, 2004; Wang et al., 2008; Yu et al., 2010). The larvae develop to the doliolaria and pentactula stages and then metamorphose to early juveniles after one or two days. Attachment substrates are necessary in the rearing tank when the behavior of the juveniles changes from swimming to settlement. The sea cucumber juveniles are moved to ponds for farming or to the open sea for restocking or sea ranching when they grow to $2-3 \mathrm{~cm}$ (Chen, 2003). The larval settlement of sea cucumbers requires the strict management of environmental conditions, including temperature, $\mathrm{pH}$, salinity, dissolved oxygen (DO), illumination, heavy metal concentration, turbidity, ammonia nitrogen, and substratum types (Chang and Chen, 2008). The optimum temperature should be $17-19^{\circ} \mathrm{C}$. The salinity should be between 26.2 and 32.7. The DO should be over $5 \mathrm{mg} / \mathrm{L}$. The $\mathrm{pH}$ should be between 8.10 and 8.30 . The ammonia concentration should be below $0.2 \mathrm{mg} / \mathrm{L}$ (Xie, 2004; Ministry of Agriculture, 2006).

\section{Nursery of juveniles}

The juveniles develop tube podia shortly after the attachment of the pentactula to the substrate, and the common substrates for the attachment of postlarval A. japonicus are corrugated plates (Hatanaka, 1996; Ito and Kitamura, 1997). Sea cucumber A. japonicus juveniles mainly feed on benthic diatom, and formulated diets, containing mashed fresh macroalgae (e.g., Sargassum thunbergii), are also effective. A balanced and contamination-free diet is crucial for both survival and growth rate (Chang and Chen, 2008). Continuous aeration should be provided after attachment to substrate (Yu et al., 2010), and water exchange should be conducted twice daily, with approximately $1 / 3$ of the total volume exchanged each time. Numerous copepods (e.g., Microsetella sp.) often compete for the diet and damage the sea cucumber juveniles, and trichlorfon can be effective in killing these pests (Wang et al., 2005a). Antibiotics can also 
be used to prevent the outbreak of pathogenic microorganisms from the substratum.

\section{Culture models and sea cucumber production}

In this review, stock enhancement and sea ranching are distinguished as follows: Stock enhancement is a step in rehabilitating wild stocks of native sea cucumber species in their native environment either for conservation or to rehabilitate or enhance a sea cucumber fishery. Stock enhancement methods may include the introduction of hatchery-reared sea cucumbers or wild-caught sea cucumbers translocated from other places and the rehabilitation or modification of habitats to improve conditions for sea cucumber egg production, recruitment, growth, or the survival of naturally occurring stocks in that region. Sea ranching is a method of farming or increasing the production of a natural or modified habitat by the introduction of hatchery-reared sea cucumbers or wild-caught sea cucumbers translocated from other places to an area of water or section of coast with prescribed boundaries for the express purpose of later reharvesting the same individuals. In some cases, the only distinction between stock enhancement and ranching will be the exclusivity of harvest rights over a section of water or coastline (Bell et al., 2008a).

To meet the huge commercial demand and protect the wild sea cucumber from overexploitation, pond aquaculture, sea ranching, and stock enhancement are the most feasible and eco-friendly solutions. Australia, China, Indonesia, Kiribati, Philippines, Vietnam, and Madagascar have started such ventures (Toral-Granda et al., 2008; Purcell et al., 2012). China successfully produced an estimated 130,000 tons of fresh weight (Table 1) A. japonicus from aquaculture, mainly to supply local demand. This value is of the same order of magnitude as the total world wild catch (Toral-Granda et al., 2008). Restocking is an expensive remedy to overfishing. In spite of this, sea cucumber aquaculture is still in the early development stages in the Asia Pacific region, culturing only one popular and commercial important species, $A$. japonicus. Trials to ascertain the commercial viability of culture and farming options of the sea cucumber Holothuria scabra have been undertaken in Australia, Fiji, India, Indonesia, Iran, Madagascar, Maldives, New Caledonia, Philippines, Saudi Arabia, Solomon Islands, Vietnam, and Micronesia (Purcell et al., 2006; Toral-Granda et al., 2008; Purcell et al., 2012).

\section{Pond and tank grow out of sea cucumbers in aquaculture}

Recently, farming sea cucumbers in either new ponds or those previously used for shrimp aquaculture has become increasingly popular in northern China ( $\mathrm{Yu}$ et al., 1998). Suitable ponds are those located at the lower tide level for the convenience of water exchange and must be free of pollution or contamination. The optimum temperature for sea cucumber growth is $10-17^{\circ} \mathrm{C}$, but juveniles can maintain high growth rates at $24-25^{\circ} \mathrm{C}$. Salinity should be maintained above 27 all year (Zhang and Liu, 1998). Sandy or sandmuddy bottom is the preferred sediment type for sea cucumber aquaculture. The depth should be more than $2 \mathrm{~m}$ (no less than $1.5 \mathrm{~m}$ ). The optimal pond size is approximately $2-6$ ha and be able to be cleaned thoroughly in the event of a bloom of microalgae or other harmful organisms. Ponds must be protected from typhoons or strong waves (Chang et al., 2004; Xue, 2007).

Providing suitable substrata such as stones, bricks, and roof tiles is necessary for the juvenile sea cucumbers in order to protect against predators, increase the availability of natural feed such as benthic algae and accumulating organic debris, and improve the habitat for aestivation and hibernation (Jia and Chen 2001; Mu, 1999). The substrate materials should be introduced one month before the introduction of the sea cucumber juveniles to allow them to leach any impurities and so natural biofilms to accumulate on them (Chang et al., 2004; Xue, 2007). Macroalgae and sea grass should also be translocated into the ponds to provide a food source and shelter for sea cucumbers (Yu et al., 2010).

In the northern China, the stocking season begins between March and May with stocking density depending on the size of the juveniles and habitat conditions, including natural feed availability and seawater exchange rate. Sea cucumber juveniles can grow from 10 to $150 \mathrm{~g}$ by October or November; however it will take 15-18 months to reach commercial size if the body weight of stocked juveniles is less than $1 \mathrm{~g}$ (Chen, 2003). Sea cucumbers need very low-frequency applications of artificial feed, and natural food in the form of suspended organic matter brought by water exchange can be sufficient, especially in summer and winter. Sea cucumber farming is more straightforward than shrimp aquaculture due to lower water exchange needs and no requirement for artificial aeration. These factors along with lower routine management costs have resulted in a shift from shrimp aquaculture to the more lucrative and profitable sea cucumber farming (Xue, 2007; Guan and Wang, 2009).

\section{Sea ranching of sea cucumbers}

Ranching usually occurs in restricted natural environments where juveniles are released and adults are fished (Tseng, 1979; Jia and Chen, 2001). Sea ranching of sea 
cucumbers has become popular in recent years and was initiated by the Yellow Sea Fisheries Research Institute in 1980. The keys to success are site selection and appropriate routine management.

The ranching farm sites have a series of requirements. The sites should be abundant in nutrients, with rocky stone substrate abundant in macroalgae or sandy mud sediment in the presence of Zostera sea grass. The sites should be open, with low current or tides and avoiding areas with input of freshwater from runnoff and strong currents. The depth should be $2-15 \mathrm{~m}$. The physical and biological environment of the site maybe improved with additional shelter if required Xie, 2004; Yu et al., 2010). Sea ranching ideally occupies a large area and has a low population density (3-15 individuals per square meter, by Dr. Xin Jiang, personal communication). Juveniles larger than $3 \mathrm{~mm}$ are recommended for stocking in sea ranching as a higher survival rate can be obtained (Xie, 2004).

This aquaculture model has become increasingly popular due to its perceived eco-friendly sustainability (relative to coastal ponds) and significantly better profit and product quality (Xue, 2007).

\section{Stock enhancement of sea cucumbers}

Sea cucumber populations depleted through overfishing recover slowly, if at all (Uthicke et al., 2004). Stock enhancement may assist recovery, and this has led to interest in many countries over the last 20 years (Chang and Chen, 2008). Stock enhancement of sea cucumbers has been practiced in Japan since the 1980s by releasing large quantities of artificially produced juveniles into coastal waters (Yokoyama, 2013). However, in China, it is still in its infancy, and more refinement is needed to optimize results (Jia and Chen, 2001). The potential for stock enhancement to replenish sea cucumber stocks in the Seychelles is also being considered (Aumeeruddy and Payet 2004). Battaglene and Bell (1999) argued that $H$. scabra was a suitable candidate for stock enhancement based on rearing trials demonstrating that this species was easy to culture and grew rapidly at high densities. They suggested wild release could be occur at 2-3 months of age or approximately $20 \mathrm{~mm}$ in length, but further research is required to attain maximum survival.

Bell and Nash (2004) discussed the rationale for the stock enhancement of sea cucumbers, proposing that a strong economic case must be made before restocking should proceed. Their synthesis was based on the premise that restocking must be driven by the consideration of whether the cost of stock enhancement to rapidly rebuild a fishery is justified on the basis of additional financial returns. Bell and Nash (2004) also noted the importance of considering metapopulation structures in sea cucumbers when considering stock enhancement. Schroeter et al. (2001) demonstrated the utility of marine sanctuaries by contrasting the abundance of sea cucumbers between fished and unfished habitats, demonstrating the potential role of marine sanctuaries in helping to rehabilitate sea cucumbers.

Later in this review, the issue of loss of genetic diversity in hatchery-reared sea cucumbers is discussed; however, in general, stock enhancement is a positive measure as it can enhance or rehabilitate declining resources. However, numerous factors can influence whether it is successful. Survival rates of sea cucumber juveniles may be lower than $10 \%$ because of poor environmental adaptation and loss of small juveniles carried away by currents or tides (Wu et al., 1996) and a range of other environmental or biological factors may influence mortality and recapture rates in open seas.

\section{Sea cucumbers in polyculture}

Usually, cultured organisms (e.g., shrimps or fishes) need frequent feeding of artificial diets, and excessive feed and feces deposited onto the seabed can lead to organic accumulation. This can greatly increase oxygen demand of the substrate and result in a succession of the benthic community toward more hypoxia-tolerant species. However, as deposit feeders, sea cucumbers in pond culture usually do not require feed supplementation. Organic matter brought in during sea water exchanges are generally sufficient to maintain the level of food availability required by sea cucumbers. However, additional feed and organic detritus could be helpful to achieve a faster growth rate and maintain a higher rearing density, especially in spring and autumn (Chang et al., 2004). Therefore, sea cucumber can be cultured together with some species which have complementary feeding habits and which produce additional organic enrichment of the pond sediment. These species include fishes, abalone, shrimp, bivalves-algae, and jellyfish (Xue, 2007; Yu et al., 2010), and this type of polyculture can also be named integrated multitrophic aquaculture (Nelson et al., 2012). Coculture systems of sea cucumber and other organisms have both environmental and economic benefits, and these methods could contribute to the sustainable development of aquaculture in China (Chang and Chen, 2008; Yu et al., 2012). Sea cucumber can efficiently ingest and assimilate the excessive feed and feces in the coculture system, which can be helpful to the water quality.

\section{Sea cucumber-shrimp}

In addition to culturing sea cucumber alone, ponds are also widely used for polyculture with different species of 
shrimps, such as Chinese or Japanese shrimp species (Chang et al., 2004; Chang and Chen, 2008). Coculture of sea cucumbers (Holothuria leucospilota) has a positive effect on the growth and survival of shrimps (Litopenaeus vannamei), and shrimps have no adverse effect on sea cucumbers (Yu et al., 2012). Sea cucumbers make full use of the organic matter from excess shrimp food and feces, providing both ecological and economic benefits (Chang et al., 2004; Purcell et al., 2006; He et al., 2008; $\mathrm{Yu}$ et al., 2012). The shrimp postlarvae are usually released between May and June from the wild or from hatcheries, ranging from $2-10 \mathrm{~cm}$ in length. In common with other types of pond culture, many factors influence the stocking density of sea cucumber, including pond conditions, body size of juveniles, food supply, and availability of settlement substrates (Chang and Chen 2008). The amount of sea cucumber juveniles released also depends on the body size of the individuals (Chang and Chen, 2008). Seawater is exchanged by opening and closing the sluice gates during tidal change. In summer, water temperature can be lowered to avoid aestivation by maintaining higher water levels in ponds. Important environmental factors such as temperature, salinity, $\mathrm{pH}$, and oxygen levels should be monitored daily and maintained within favorable ranges. Moreover, the growth, survival rate, and behavior of the sea cucumbers also need to be monitored (Chang and Chen, 2008). The sea cucumbers perform best in leak-proof ponds with muddy sand bottoms and reach commercial size 1.01.5 years later (Chang et al., 2004).

The coculture of the sea cucumber, $H$. scabra (sandfish) had no detrimental effect on the growth or survival rate of the cocultured shrimps, Penaeus monodon, and Litopenaeus stylirostris (Purcell et al., 2006). Meanwhile, shrimps exert both positive and adverse effects on sea cucumbers. Shrimps can help improve benthic conditions by eating excessive food, but are also responsible for the deaths of some sea cucumbers (Pitt et al., 2004) and for increasing the total ammonia concentration, which can be harmful for sea cucumber growth (Purcell et al., 2006).

\section{Sea cucumber-molluscs}

There are several examples of successful polyculture trials involving sea cucumbers and different molluscs. Biodeposition from suspended mollusc aquaculture increases the local deposition of organic matter to the benthic environment (Graf and Rosenberg, 1997; Zhou et al., 2006). Sea cucumbers can improve both the water quality and the growth of the cocultured mollusks (Xue, 2007). The concentrations of ammonium nitrogen and nitrite in coculture ponds were lower than in the abalone monoculture (Haliotis discus hannai), and the abalone achieved a better growth performance and higher survival rate (Kang et al., 2003; Xue, 2007). Sea cucumber Australostichopus mollis also showed excellent survivorship and exhibited higher growth than natural population when co-cultured with green-lipped mussel (Perna canaliculus), and slow growth rate of sea cucumber only occurred at high densities $\left(15 \mathrm{~m}^{-2}\right)$ due to food limitation in New Zealand (Slater and Carton, 2007). Growth and production of California sea cucumbers ( $P$. californicus Stimpson) cocultured with suspended Pacific oysters (Crassostrea gigas Thunberg) was also investigated in the field, and the successful utilization by sea cucumbers of the naturally available biodeposits from the oysters suggests that this possible commercial-scale coculture system would both reduce the amount of organic deposition underneath shellfish farms and produce extra benefits (Paltzat et al., 2008).

\section{Sea cucumber-bivalves-algae}

Polyculture of sea cucumbers with bivalves and algae has relatively high ecological and economic benefits. As deposit feeding scavengers in the aquaculture system, sea cucumbers can reduce the organic deposits (Yang et al., 2000). Yang et al. (2000) compared the performance between scallop monoculture and scallop-kelp-sea cucumber polyculture and found that polyculture systems provide a much better scallop output.

Several studies have described the potential for both productivity and improvement in scallop muscle quality from sea cucumber polyculture systems (Dong et al., 2007; Yuan et al., 2008). Some studies sought to derive benefits for the other species being cultured, principally by reducing waste released by salmon, scallop, and mussel farms. Few studies investigated the economic benefits or demonstrated the commercial feasibility of producing sea cucumbers in polyculture (Yu et al., 1998). China is the only country where ocean ranching polyculture of sea cucumbers with bivalves and algae has been widely practiced on a commercial scale.

\section{Sea cucumber-fishes}

Ahlgren (1998) found increased growth and muscle development of the sea cucumber $P$. californicus in salmon cages in Alaska, because the excessive feed and salmon waste can be consumed significantly faster than the natural sediment diet for sea cucumber (Nelson et al., 2012). Polyculture of sea cucumbers and salmon could provide dual benefits of cage cleaning and marketable sea cucumber products. It is also feasible to culture A. japonicas with fishes because of the higher survival and growth rates owing to the protection and nutritional feed provided by fish cages (Nelson et al., 2012; Yokoyama, 2013). 


\section{Diseases affecting sea cucumbers in aquaculture}

Along with the rapid development of sea cucumber farming in China, various diseases have afflicted this industry from its beginning and the resultant high mortalities are a barrier for sustainable development. There have been numerous studies on disease in $A$. japonicus in northern China (Table 2).

There have been some studies on parasites, including sporozoans, turbellarians, and gastropods, in wild sea cucumbers (Smith, 1984; Jangoux, 1987a, b; 1990) but more pests and diseases occur during intensive aquaculture causing high mortality. Previous research has revealed that many mortalities were caused by the combined effects of different agents, including bacteria, fungi, parasites and copepods. Amongst these pathogens, bacteria are the most significant etiological agent, followed by parasites and fungi (Wang et al., 2005b). Both bacteria and viruses were implicated in diseases affecting larval, juvenile, and adult life stages. The diseases can occur during all stages of cultivation, e.g., breeding, aestivation, and outdoor cultivation. Although much focus and effort has been dedicated to studying sea cucumber diseases, this remains in its infancy and it is often difficult to reveal which pathogens were responsible for symptoms.

The exact pathogenic agents must be identified and then the most effective antibiotic or other remedy can be chosen; however, preventative measures and hygienic cultivation practices are more economically and environmentally desirable. These precautions include collection of healthy broodstock, not exceeding optimum stocking density, high-quality artificial diets and maintaining high levels of water quality. As soon as disease is detected, infected or moribund individuals should be removed from the tanks or ponds. Antibiotics should only be used when pathogenic agents have been confirmed and when antibiotics are known to be effective against them (Wang et al., 2005b). Pesticides are often used to control seaweed or invertebrate pests; however, these chemicals must be specific against the target and not harmful to the sea cucumber. The biodegradability of these chemicals is also a concern, as the potential residue could affect both the environment and the sea cucumbers. Any food safety problems that arise from chemical use could lead to a crisis of confidence in the industry.

\section{Sea cucumber aquaculture and the environment}

\section{Influence of sea cucumber aquaculture on the environment}

\section{Genetic diversity of wild sea cucumber stocks}

Long-established alleles of local strains may be responsible for adaptation to the local environmental or biotic stressors (Purcell et al., 2012), and the introduction of stock from non-local population is potentially harmful to the genetic diversity. Ensuring the security of genetic diversity is important because of the potential risk to wild sea cucumber stocks (Uthicke and Purcell, 2004). Both overexploitation and aquaculture of holothurians can exert negative effects on genetic diversity. Overexploitation, especially if it is selective for larger or faster growing animals can lead to changes in population size structure and reduced population size can lead to inbreeding and the loss of genetic diversity can elevate extinction risk of aspecies (Choo, 2008). Moreover, overfishing will decrease the population density, and for animals like sea cucumbers which are broadcast spawners this can result in lowered reproductive success when the population density falls below the threshold required for successful fertilization. (Bell et al., 2008b). Hatcheryproduced sea cucumbers can reduce genetic diversity in wild stocks in two ways. Broodstock from different genetic stock will reduce genetic differences among stocks by the introgression of exogenous alleles and the reduction of native alleles in frequency (Utter, 1998). Meanwhile, "outbreeding depression" will be caused by interbreeding of introduced stock and the native stock, and hybridizations tend to have long-lasting effects that are disadvantageous to native stocks rather than being beneficial by adding genetic variation (Hindar et al. 1991; Uthicke and Purcell, 2004).

In China, outcrossing broodstock are rarely introduced into hatcheries and the same broodstock are used to produce multiple generations due to the difficulty in collecting large numbers of sexually mature, wild A. japonicus (Chen et al., 2008). This presents a risk of loss of genetic diversity of broodstock in these hatcheries and the seed stock they produce; however, microsatellite markers have been applied to compare genetic differentiation within and among wild and hatchery stocks in northern China, and to date has shown no significant decrease of genetic variability of the cultured stocks despite the potential risk (Chen et al., 2008).

In New Caledonia, the tropical sea cucumber H. scabra exhibited a pattern of isolation by geographic distance (Uthicke and Purcell, 2004), and the spatial extent of any translocation must therefore be carefully considered on the basis of the knowledge of variation in allele frequencies within the target area. Juveniles should be released only at native sites to preserve the genetic diversity of stocks with the information on genetic structure of stock at release and source sites (Shaklee and Bentzen 1998). Careful choice of broodstock is required even when native populations are used as sea cucumbers are highly fecund and using small numbers of adults can 


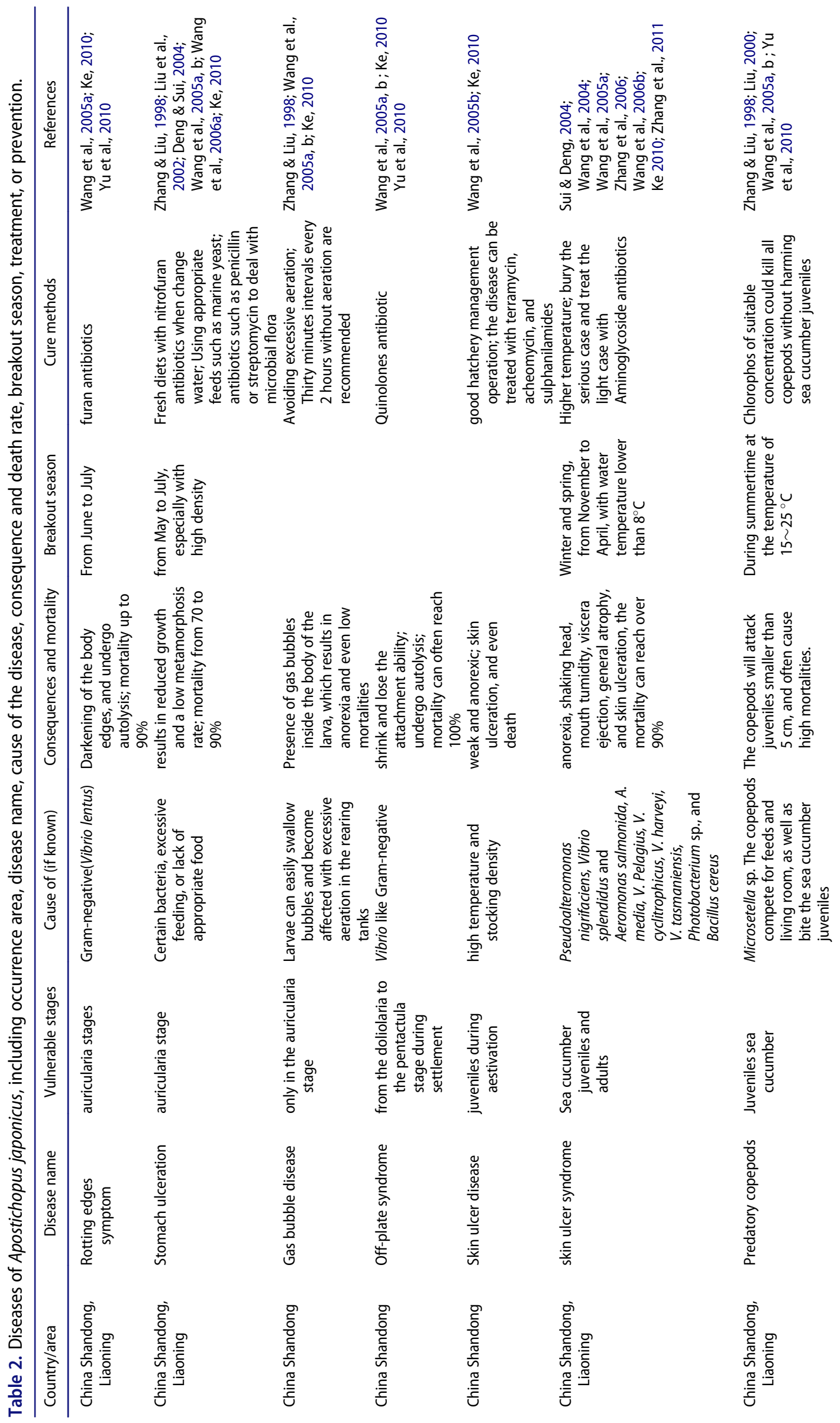


REVIEWS IN FISHERIES SCIENCE \& AQUACULTURE

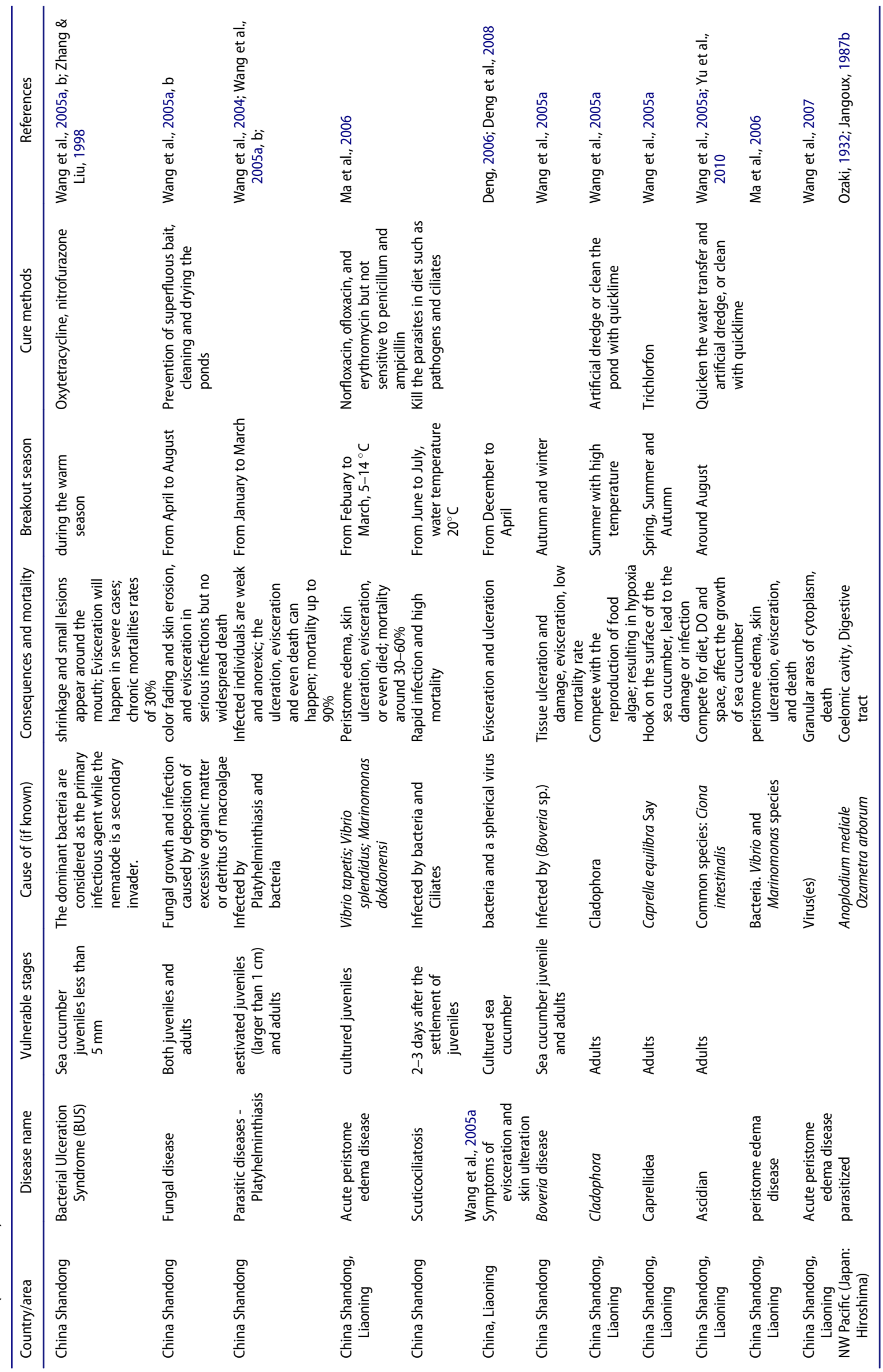


limit the genetic diversity expressed in the seed stock (Ryman et al. 1995).

Good management to preserve native breeding populations should be the first solution, as there are risks to changing the genetic diversity of existing stocks when juveniles are released for restocking or stock enhancement. Restocking should only be the last resort if other management measures to recover a depleted fishery have failed (Uthicke and Purcell, 2004). To date, there has been interest in identifying the genetic population structure of various species of sea cucumber (Uthicke and Benzie, 2001) to ensure that hatchery-reared juveniles are produced and released in ways that do not affect the natural genetic diversity of the species. There can be marked differences between populations at relatively small spatial scales in $H$. scabra. The fisheries for these valuable species are exploit largely self-recruiting populations, and each population should be managed separately (Bell and Nash, 2004).

\section{Eutrophication}

Conand and Mangion (2002) showed that Holothuria atra and $\mathrm{H}$. leucospilota had higher densities in eutrophied areas of the Reunion Islands (e.g., Planch' Alizes) compared to relatively healthy bays and concluded that a high level of eutrophication probably results in a greater availability of organic material favorable for sea cucumbers. Thus, sea cucumbers should benefit from this excessive concentration of nutrients in the water, but the threshold of eutrophication needs further research as the concentration of nitrite has been shown to have a direct negative correlation with the growth of sea cucumber (H. scabra) (Yao et al., 2007).

\section{Habitat modification, damage, or disturbance}

Sea cucumbers can exert bioturbation effects on the benthic environment (Bakus, 1973), which are essential to the benthic ecological system. They are responsible for the recycling of detritus and the mixing of substrate. They ingest sediment and organic matter together and grind it into smaller particles. This behavior helps to break up and shuffle the top layer of sediment to allow the penetration of oxygen (Sloan and Bodungen, 1980) and has significant ecological efficiency in the deposition and recycling of organic matter and nutrients (Liu et al., 2006; Yuan et al., 2008). However, sea cucumbers have little effect on habitat modification, and they usually select favorable habitats rather than modify the environment to suit them. Coastal processes are also important factors in regulating the distribution of sea cucumber species, as hydrodynamics influence larval dispersion and sediment granulometry, which is a key habitat characteristic for defining the niches of holothurian species (Massin and Doumen, 1986). They prefer sediment with abundant organic matter (Mahmoud and Ahmad, 2006) and are distributed in different patches in the natural environment (Uthicke and Karez, 1999; Bell and Nash, 2004). They also show preference for particular ranges of sediment particle size (Uthicke and Karez, 1999; Mercier et al., 2000) and the high diversity of sea cucumbers on tropical coral reefs is thought to be a reflection of the broad range of habitats available (Kinch et al., 2008). Sea cucumber distribution is also assumed to be influenced by food availability, and in China it has been shown that there are more bacteria and organic matter where sea cucumbers live (Liao, 1997); however, the relationship between sea cucumber, sediment, and bacteria is complicated and needs better definition.

\section{Influence of the environment on sea cucumber aquaculture}

\section{Substrate}

The sea cucumber A. japonicus prefers to live in substrates with rocks and stones, coupled with abundant marine algae or seagrass at depths of 3-35 m (Yu et al., 2010). Sea cucumbers will aggregate in higher densities and grow faster on a coarse sand and stone seabed. Otherwise, sea cucumbers have a lower density and grow more slowly (Xing and Wang, 2000; Yu et al., 2010). A. japonicus usually live on substrate with silt content less than $10 \%$, and few sea cucumbers occur where the silt content is over 20\% (Xie, 2004; Yu et al., 2010). Some attempts at sea cucumber aquaculture using raft culture have overcome unfavorable natural conditions such as strong current or unsuitable substrate (Liu et al., 2006).

\section{Temperature}

The holothurians are distributed all over the world's oceans, and some species can adapt to a wide range of temperature and even recover from a near frozen state (Ke, 2010). As a temperate species, the sea cucumber is sensitive to temperature variations in ambient water (Dong and Dong, 2006), and the thermal tolerance range of A. japonicus is between sub-zero and $30^{\circ} \mathrm{C}$ (Dong et al., 2005). The optimum temperature for juvenile growth is between 12 and $22^{\circ} \mathrm{C}$ (Zhang and Liu, 1998; Dong et al., 2005; Dong and Dong, 2006). Adult grow the fastest between 10 and $21^{\circ} \mathrm{C}$ (Zhang and Liu, 1998; Xing and Wang, 2000; Dong et al., 2005). Sea cucumbers reduce their activity and food consumption when the ambient temperature exceeds $17^{\circ} \mathrm{C}$ or is below $3^{\circ} \mathrm{C}$ (Xing and Wang, 2000) or is warmer than $20^{\circ} \mathrm{C}$ ( $\mathrm{Yu}$ et al., 1998). Sea cucumber A. japonicus ceases feeding 
and growing when water temperatures exceed $20^{\circ} \mathrm{C}$, the threshold temperature for aestivation (Wu et al., 1996; Xing and Wang, 2000; Xie, 2004; Dong et al., 2005; Yang et al., 2005; Yu et al., 2010). Sea cucumber aestivation might occur in response to a shortfall in energy intake with respect to increased energy consumed in respiration at high temperature. The sea cucumber decreases its energy requirement and metabolic rate by aestivation when the ambient temperature exceeds the threshold point (An et al., 2007). If the amplitude of temperature fluctuations is approximately $\pm 2^{\circ} \mathrm{C}$ between $15-18^{\circ} \mathrm{C}$, this temperature variation will maintain sea cucumbers at the highest growth rate (Yang et al., 2005). The optimum temperature for a juvenile nursery is $23-27^{\circ} \mathrm{C}$ or $21-24^{\circ} \mathrm{C}$ (Yang et al., 2005; $\mathrm{Li}$ and $\mathrm{Li}, 2010$ ). The juveniles become torpid and suffer a high mortality rate when the temperature is below $21^{\circ} \mathrm{C}$ or above $30^{\circ} \mathrm{C}(\mathrm{Yu}$ et al., 2010).

Temperature does not affect the survival of tropical sea cucumber juveniles of $H$. scabra, but it greatly affects their growth. The juveniles can survive at $39^{\circ} \mathrm{C}$ water temperature. Above this they become weak, and they die at $41^{\circ} \mathrm{C}$. Growth is positively correlated with temperature variation between 28 and $31^{\circ} \mathrm{C}$ (Yao et al., 2007; Lavitra et al., 2010). The optimum temperature for adult growth is $20-30^{\circ} \mathrm{C}$, with the fastest rate at $25^{\circ} \mathrm{C}$; however, $\mathrm{H}$. scabra will stop feeding at $15^{\circ} \mathrm{C}$ (Yao et al., 2007).

\section{Salinity}

Almost all Holothuroidea are stenohaline, so it is important to avoid sea cucumber aquaculture in areas subject to fresh water injection (Xing and Wang, 2000). The optimum salinity for sea cucumber (A. japonicus) is 2732, but can vary from 24.2 to 34.7 (Xing and Wang, 2000; Xie, 2004; Chen et al., 2007; Yu et al., 2010). Sea cucumbers (A. japonicus) tolerate chronic salinity fluctuations at a range of 22-36 and grow better between 27 and 31.5, but decrease at higher or lower salinity (Yuan et al., 2010). The larvae of sea cucumber (A. japonicus) showed maximum growth and survival rate at salinity 30 (Li and Li, 2010).

\section{Oxygen and $\mathrm{pH}$}

The sea cucumber $A$. japonicus can endure low oxygen concentration. They are only negatively affected when the oxygen concentration is lower than $1 \mathrm{mg} / \mathrm{L}$ for adults or $3.3 \mathrm{mg} / \mathrm{L}$ for juveniles. They lose their adhesive ability, with stiff body and abdomen turning upside down (Xing and Wang, 2000; Yu et al., 2010). A. japonicus juveniles die when the dissolved oxygen is lower than $1 \mathrm{mg} / \mathrm{L}$ ( $\mathrm{Yu}$ et al., 2010). Adult sea cucumbers consume $0.4-0.8 \mathrm{mg} / \mathrm{L}$ oxygen per hour under normal activities. Oxygen consumption rates at most fluctuating temperatures were lower than those at corresponding constant temperatures and this may affect growth rates (Dong and Dong, 2006).

Sea cucumbers can adapt to a wide range of $\mathrm{pH}$, from 6.0 to 9.0 (normally sea water $\mathrm{pH}$ is $7.9-8.2$ ), and sea cucumber juveniles will shrink or even die if the $\mathrm{pH}$ exceeds this threshold (Zhang and Liu, 1998; Yu et al., 2010). Too low or too high $\mathrm{pH}$ values usually relate to lower dissolved oxygen values or to the presence of toxic ammonia $\left(\mathrm{NH}_{3}\right)$. It is therefore important to adjust the $\mathrm{pH}$ value and maintain the water quality ( $\mathrm{Yu}$ et al., 2010).

\section{Position in the foodweb}

Sea cucumbers are crucial components of marine food webs. Adult sea cucumbers usually have few natural predators besides some sea stars and sea birds. The sea cucumber juveniles are preyed on by crabs and sea breams (Xing and Wang, 2000). Some tropical sea cucumber have fish predators, although there is relatively little predation due to toxins found in the body wall (Hammond, 1982). They are sometimes referred to as the earthworms of the sea because they are responsible for the recycling of detritus and mixing of substrate and they help control the populations of marine pests and pathogens in the sediments.

Sea cucumbers obtain food using their shield-shaped (peltate) tentacles (Ke, 2010) and are selective of particle size but not of food source. In areas where there are coexisting holothurians, each species tends to selectively ingest different sized sediments (Sloan and Bodungen, 1980). Sea cucumbers can be divided into two groups according to feeding habits; detritus feeders and suspension feeders. The food items of deposit-feeding sea cucumbers include microorganisms (benthic diatoms, bacteria, cyanophyta, and foraminifera), organic debris of animals and plants, inorganic matter (Silicon and Calcium), and animal feces (including their own) (Choe and Ohshima, 1961; Yingst, 1976; Hauksson, 1979; Sloan and Bodungen, 1980; Moriarty, 1982; Zhang et al., 1995; Uthicke and Klumpp, 1998; Kang et al., 2003). More than $90 \%$ of the intestinal content of the holothurian Stichopus tremulus was siliceous debris, planktonic foraminifera constituted approximately $3.6 \%$, and the remainder contained benthic foraminifera, plant residue, and feces (Hudson et al., 2004). The diet of suspensionfeeding sea cucumbers includes microalgae, protozoa, nemathelminthes, copepod larvae, and diatoms (Ke, 2010).

\section{Storms and other weather events, global warming, and other perturbations}

Both warm temperatures and shallow habitats permit easy harvesting by coastal fishers and make these 
fisheries vulnerable to degradation from impacts associated with global climate change. When gales or storms arrive, sea cucumbers often hide in stone holes or sea grass (Yu et al., 2010). Macroalgal blooms, caused by Ulva prolifera, have become an annually recurrent feature in the Yellow Sea, and these have caused significant economic damage to sea cucumber aquaculture (Liu et al., 2013). The macroalgal blooms will produce quantities of ammonium and sulfide during the decomposition of $U$. prolifera, which is toxic to sea cucumbers. In the semi-enclosed aquaculture ponds, the hypoxic conditions caused by the respiration or decomposition of green algae can deteriorate water quality and lead to high sea cucumber mortality (Wang, 2010).

\section{Future opportunities and challenges}

The development of extensive sea cucumber aquaculture has resulted from continuous advances in all nursery practices and grow-out procedures, especially for $A$. japonicus in northern China. Meanwhile, tropical sandfish mariculture is still constrained by unreliable and low survival rates of juveniles in hatcheries (Purcell et al., 2012). In China, polyculture, and ocean ranching methods enhance aquaculture system sustainability, reducing environmental risk and increasing profits.

Overall, the success of sea cucumber aquaculture is determined by having optimum environmental conditions and sound scientifically based husbandry practices but increased human activity along the coastline can increase the cultivation risk, e.g., sewage discharge, oil spills, eutrophication, and hypoxia. Many diseases and parasites occur during culture, particularly in pond aquaculture. Thus, it is necessary to have effective procedures for diagnosis of pathogenic agents and employ antibiotic or pest eradication treatments carefully. Further research is needed to determine the pathogenic agents and the safest and most effective treatments can be chosen.

\section{Funding}

This work was sponsored by the Natural Science Foundation of China (41376121), the Strategic Priority Research Program of the Chinese Academy of Sciences (XDA11020405), Natural Science Foundation of Shandong Province (JQ201414), the Open Fund of Zhejiang Provincial Top Key Discipline of Aquaculture in Ningbo University (No. xkzsc1407) and also partly sponsored by K.C. Wong Magna Fund in Ningbo University.

\section{References}

Ahlgren, M. O. Consumption and assimilation of salmon net pen fouling debris by the Red Sea cucumber Parastichopus californicus: Implications for polyculture. J. World Aquac. Soc., 29: 133-139 (1998).

An, Z. H., Y. W. Dong, and S. L. Dong. Temperature effects on growth-ration relationships of juvenile sea cucumber Apostichopus japonicus (Selenka). Aquaculture, 272: 644-648 (2007).

Aumeeruddy, R., and R. Payet. Management of the Seychelles sea cucumber fishery: status and prospects. FAO Fish. Tech. Pap., 463: 239-246 (2004).

Bakus, G. J. Some effects of turbulence and light on competition between 2 species of Phytoplankton. Invest. Pesq., 37: 87-99 (1973).

Battaglene, S. C., and J. D. Bell. Potential of the tropical IndoPacific sea cucumber, Holothuria scabra, for stock enhancement, pp. 478-490. In: Stock Enhancement and Sea Ranching. (Moksness, E., and T. Svasand Eds.). Oxford: Blackwell Science (1999).

Bell, J. D., and W. Nash. When should restocking and stock enhancement be used manage sea cucumber fisheries. FAO Fish. Tech. Pap., 463: 173-179 (2004).

Bell, J. D., K. M. Leber, H. L. Blankenship, N. R. Loneragan, and R. Masuda. A New Era for Restocking, Stock Enhancement and Sea Ranching of Coastal Fisheries Resources. Rev. Fish. Sci., 16(1-3): 1-9 (2008a).

Bell, J. D., S. W. Purcell, and W. J. Nash. Restoring small-scale fisheries for tropical sea cucumbers. Ocean Coast. Manage., 51: 589-593 (2008b).

Botting, J. P., and L. A. Muir. Fauna and ecology of the holothurian bed, Llandrindod, Wales, UK (Darriwilian, Middle Ordovician), and the oldest articulated holothuria. Palaeontol. Electron., 15(1): 1-28 (2012).

Bruckner, A.W., K. A. Johnson, and J. D. Field. Conservation strategies for sea cucumbers: Can a CITES Appendix II listing promote sustainable international trade? SPC Bêche-demer Inf. Bull., 18: 24-33 (2003).

Chang, Y. Q., and J. X. Chen. The status of mariculture in northern China. FAO Fish. P., 11: 271-284 (2008).

Chang, Y. Q., C. Q. Yu, and X. Song. Pond culture of sea cucumber, Apostichopus japonicus, in Dalian, pp. 269-272. In: Advances in sea cucumber aquaculture and management. (Lovatelli, A., C. Conand, S. Purcell, S. Uthicke, J. F. Hamel, and A. Mercier Eds.). Rome: FAO (2004).

Chen, J. X. Overview of sea cucumber farming and sea ranching practices in China. Bêche-de-mer Inf. Bull., 18: 18-23 (2003).

Chen, J. X. Present status and prospects of sea cucumber industry in China, pp. 25-32. In: Advances in sea cucumber aquaculture and management. (Lovatelli, A., C. Conand, S. Purcell, S. Uthicke, J. F. Hamel, and A. Mercier Eds.). Rome: FAO (2004).

Chen, L. M., Q. Li, and J. M. Yang. Microsatellite genetic variation in wild and hatchery populations of the sea cucumber (Apostichopus japonicus Selenka) from northern China. Aquac. Res., 39: 1541-1549 (2008).

Chen, Y., F. Gao, G. S. Liu, L. P. Shao, and G. F. Shi. The effects of temperature, salinity and light cycle on the growth and behavior of Apostichopus japonicus. J. Fish. China, 31(5): 687-691 (2007) (in Chinese with English Abstra)

China Fisheries Yearbook. China Bureau of Fisheries, 19892015. Beijing: China Agriculture Press (2015). (in Chinese). 
Choe, S., and Y. Ohshima. On the morphological and ecological differences between two commercial forms. "Green" and "Red", of the Japanese common sea cucumber, Stichopus japonicus Selenka. Bull. Japanese Soc. Sci. Fish., 27: 97106 (1961).

Choo, P. S. Population status, fisheries and trade of sea cucumbers in Asia. FAO Fish. Aquac. Tech. Pap., 516: 81-118 (2008).

Conand, C., and P. Mangion. Sea cucumbers on La Reunion Island fringing reefs: Diversity, distribution, abundance and structure of the populations. SPC Bêche-de-mer Inf. Bull., 17: 27-33 (2002).

Conand, C. Present status of world sea cucumber resources and utilisation: an international overview. FAO Fish. Tech. Pap., 463: 13-23 (2004).

Deng, H., and X. L. Sui. Common epidemic of Apostichopus japonicus in Incubation period. Fish. Sci., 23(3): 40 (2004) (in Chinese with English Abstract).

Deng, H. A new pathogen in sea cucumber Apostichopus japonicus-a spherical virus. Fish. Sci., 25(1): 30-31 (2006) (in Chinese with English Abstract).

Deng, H., Z. C. Zhou, N. B. Wang, and C. Liu. The syndrome of sea Cucumber (Apostichopus japonicus) infected by virus and bacteria. Virol. Sinica, 23(1): 63-67 (2008) (in Chinese with English Abstract).

Dong, G.C., X. L. Tian, S. L. Dong, D. P. Wang, and J. Chang. An Experimental Study on Energy Budget and Conversion Efficiency in Different Polyculture Modes of Shrimp, Bivalve and Seaweed. J. Ocean U. China, 37(6): 899-906 (2007) (In Chinese with English abstract).

Dong, Y. W., S. L. Dong, X. L. Tian, F. Wang, and M. Z. Zhang. Effects of water temperature on growth, respiration and body composition of young sea cucumber Apostichopus japonicus. J. Fish. Sci.China, 12(1): 33-38 (2005) (In Chinese with English abstract).

Dong, Y. W., and S. L. Dong. Growth and oxygen consumption of the juvenile sea cucumber Apostichopus japonicus (Selenka) at constant and fluctuating water temperatures. Aquac. Rese., 37: 1327-1333 (2006).

Gilliland, P. M. The skeletal morphology, systematic and evolutionary history of holothurians. Spec. Pap. Palaeontol. Ser., 47: 7-147 (1993).

Graf, G., and R. Rosenberg. Bioresuspension and biodeposition: a review. J. Mar. Syst., 11: 269-278 (1997).

Guan, H. S., and S. G. Wang. China Marine Materia Medica. Shanghai: Ocean Press, Shanghai Science and technology Press (2009).

Hammond, L. S. Patterns of Feeding and Activity in Depositfeeding Holothurians and Echinoids (Echinodermata) from a Shallow Back-reef Lagoon, Discovery Bay, Jamaica. Bull. Mar. Sci., 32: 549-571 (1982).

Han, C. Y., P. H. Lin, H. Z. Xie, and Q. R. Chen. A study on key technique of Stichopus japonicas Selenka farming in southern sea area. Mod. Fish. Inf., 26(9): 31-33 (2011) (In Chinese with English abstract).

Hatanaka, H.. Density effects on growth of artificially propagated sea cucumber, Stichopus (Stichopus) japonicus juveniles. Suisan Zoshoku, 44: 141-146 (1996).

Hauksson, E. Feeding biology of Stichopus tremulus, a depositfeeding holothurian. Sarsia, 64: 155-160 (1979).

He, Z. P., X. Y. Wang, Y. F. Liu, Y. H. Liu, and X. Wang. A High Efficiency Polyculture of Sea cucumber Apostichopus japonicus with Kuruma Prawn Penaeus japonicus in pond. Fish. Sci., 27(12): 665-667 (2008). (In Chinese with English abstract).

Hindar, K., N. Ryman, and F. Utter. Genetic effects of cultured fish on natural fish populations. Canadian J. Fish. Aquat. Sci., 48: 945-957 (1991).

Hudson, I.R., B. D. Wigham, and P. A. Tyler. The feeding behaviour of a deep-sea holothurian, Stichopus tremulus (Gunnerus) based on in situ observations and experiments using a Remotely Operated Vehicle. J. Exp. Mar. Biol. Ecol., 301: 75-91(2004).

Ito, S., and H. Kitamura. Induction of larval metamorphosis in the sea cucumber Stichopus japonicus by periphitic diatoms. Hydrobiologia, 358: 281-284 (1997).

Jangoux, M. Diseases of Echinodermata. I. Agents microorganisms and protistans. Dis. Aquat. Organ., 2: 147-162 (1987a).

Jangoux, M. Diseases of Echinodermata. II. Agents metazoans (Mesozoa to Bryozoa). Dis. Aquat. Organ., 2: 205-234 (1987b).

Jangoux, M. Diseases of echinodermata. In: Kinne O (ed). Diseases of Marine Animals. Hamburg, Germany: Biologische Anstalt Helgoland (1990).

Jia, J. S., and J. X. Chen. Sea farming and sea ranching in China. FAO Fish. Tech. Paper, 418 (2001).

Kang, K. H., J. Y. Kwon, and Y. M. Kim. A beneficial coculture: charm abalone Haliotis discus hannai and sea cucumber Stichopus japonicus. Aquaculture, 216: 87-93 (2003).

Ke, Y. F. Research of sea cucumber. Qingdao: Ocean University of China Press (2010) (In Chinese).

Kinch, J., S. Purcell, S. Uthicke, and K. Friedman. Population status, fisheries and trade of sea cucumbers in the Western Central Pacific. FAO Fish. Aquac. Tech. Pap., 516: 7-55 (2008).

Lavitra, T., N. Fohy, P. G. Gestin, R. Rasolofonirina, and I. Eeckhaut. Effect of water temperature on the survival and growth of endobenthic Holothuria scabra (Echinodermata: Holothuroidea) juveniles reared in outdoor ponds. SPC Beche-de-mer Inf. Bull., 30: 25-28(2010).

Li, L., and Q. Li. Effects of stocking density, temperature, and salinity on larval survival and growth of the red race of the sea cucumber Apostichopus japonicus (Selenka). Aquac. Int., 18: 447-460 (2010).

Liao, Y. L. Editorial Committee of Fauna Sinica, Academia Sinica Fauna Sinica, Phylum Echinodermata Class Holothuroidea. Beijing: Science Press (1997) (in Chinese with English abstract).

Liu, S. A handbook of techniques on aquatic seed rearing. Beijing: The Agriculture Press (2000) (in Chinese).

Liu, X., B. X. Gu, and X. L. Zhang. Several problems in seedrearing of Apostichopus japonicus (Selenka) and corresponding activities. Mod. Fish. Inf., 17(11): 26-27(2002) (in Chinese).

Liu, S. L., H. S. Yang, Y. Zhou, T. Zhang, and X. T. Yuan. Simulative studies on utilization efficiency of Apostichopus japonicus on the biodeposit in the raft culture system in shallow sea. Mar. Sci., 30(12): 21-24 (2006) (in Chinese with English abstract).

Liu, C. B., and L. You. Situation and countermeasure of sea cucumber culturing industry in Fujian Province. J. Fujian Fish., 35(1): 64-67 (2013) (in Chinese with English abstract). 
Liu, D. Y., J. K. Keesing, P. M. He, Z. L. Wang, Y. J. Shi, and Y. J. Wang. The world's largest macroalgal bloom in the Yellow Sea, China: Formation and implications. Estuar. Coast. Shelf Sci., 129: 2-10 (2013).

Lovatelli, A., C. Conrad, S. Purcell, S. Uthicke, J. F. Hamel, and A. Mercier. Advances in sea cucumber aquaculture and management. FAO Fish. Tech. Paper, 463: 1-425 (2004).

Luan, S., H. L. Sun, and J. Kong. Heritability of auricularia larval body length for sea cucumber Apostichopus japonicus Selenka. J. Fish. Sci. China, 13(3): 378-383 (2006) (in Chinese with English abstract).

Ma, Y. X., G. R. Xu, E. P. Zhang, P. H. Wang, and Y. Q. Chang. The etiology of acute peristome edenia disease in cultured juveniles of Apostichopus japonicus. J. Fish. China, 30(3): 377-382 (2006) (in Chinese with English abstract).

Mahmoud, A. D., and H. O. Ahmad. The feeding selectivity and ecological role of shallow water holothurians in the Red Sea. SPC Bêche-de-mer Inf. Bull., 24: 11-21 (2006).

Massin, C., and C. Doumen. Distribution and feeding of epibenthic holothuroids on the reef flat of Laing Island (Papua New Guinea). Mar. Ecol., 31(2): 185-195 (1986).

Mercier, A., S. C. Battaglene, and J. F. Hamel. Periodic movement, recruitment and size-related distribution of the sea cucumber Holothuria scabra in Solomon Islands. Hydrobiologia, 440: 81-100 (2000).

Ministry of Agriculture. Standardized production of pollutionfree sea cucumber. Beijing: China Agriculture Press (2006) (in Chinese).

Moriarty, D. J. W. Feeding of Holothuria atra and Stichopus chloronotus on bacteria, organic carbon and organic nitrogen in sediments of the Great Barrier Reef. Australian J. Mar. Freshwater Res., 33: 255-263 (1982).

$\mathrm{Mu}, \mathrm{S}$. D. The techniques of farming and enhancing of Apostichopus japonicus and its present status in Shandong Province, China. Mariculture, 54: 26-28 (1999) (in Chinese).

Nelson, E. J., B. A. MacDonald, and S. M. C. Robinson. The absorption efficiency of the suspension-feeding sea cucumber, Cucumaria frondosa, and its potential as an extractive integrated multi-trophic aquaculture (IMTA) species. Aquaculture, 370-371: 19-25 (2012).

Ozaki, Y. On a new genus of parasitic Turbellaria, Xenometra and a new species of Anoplodium. J.Sci. Hiroshima Univ. Ser. B, Div., 1(5/9): 81-89 (1932).

Paltzat, D. L., C. M. Pearce, P. A. Barnes, and R. S. McKinley. Growth and production of California sea cucumbers (Parastichopus californicus Stimpson) co-cultured with suspended Pacific oysters (Crassostrea gigas Thunberg). Aquaculture, 275: 124-137 (2008).

Pitt, R., N. D. Q. Duy, T. V. Duy, and H. T. C. Long. Sandfish (Holothuria scabra) with shrimp (Penaeus monodon) coculture tank trials. SPC Bêche-de-mer Inf. Bull., 20: 12-22 (2004).

Purcell, S.W., J. Patrois, and N. Fraisse. Experimental evaluation of co-culture of juvenile sea cucumbers, Holothuria scabra (Jaeger), with juvenile blue shrimp, Litopenaeus stylirostris (Stimpson). Aquac. Res., 37(5): 515-522 (2006).

Purcell, S.W., C. A. Hair, and D. J. Mills. Sea cucumber culture, farming and sea ranching in the tropics: Progress, problems and opportunities. Aquaculture, 368-369: 68-81 (2012).

Ryman, N., P. E. Jorde, and A. L. Laikre. Supportive breeding and variance effective population size. Conserv. Biol., 9(6): 1619-1828 (1995).
Schroeter, S. C., D. C. Reed, D. J. Kushner, and J. A. Estes, and D. S. Ono. The use of marine reserves in evaluating the dive fishery for the warty sea cucumber (Parastichopus parvimensis) in California, USA. Canadian J. Fish. Aquat. Sci., 58: 1773-1781 (2001).

Shaklee, J. B., and P. Bentzen. Genetic identification of stocks of marine fish and shellfish. Bull. Mar. Sci., 62(2): 589-621 (1998).

Shiell, G. Field observations of juvenile sea cucumbers? SPC Bêche-de-mer Inf. Bull., 20: 6-11 (2004).

Slater, M. J., and A. G. Carton. Survivorship and growth of the sea cucumber Australostichopus (Stichopus) mollis (Hutton, 1872) in polyculture trials with green-lipped mussel farms. Aquaculture, 272: 389-398 (2007).

Sloan, N.A., and B. V. Bodungen. Distribution and feeding of the sea cucumber Isostichopus badionotus in relation to shelter and sediment criteria of the Bermuda Platform. Mar. Ecol. Prog. Ser., 2: 257-264 (1980).

Smiley, S., F. W. Harrison, and F. S. Chia. Microscopic anatomy of invertebrates: Echinodermata. New York: Wiley-Liss Press (1994).

Smith, T. B. Ultrastructure and function of the proboscis of Melanella alba (Gastropoda: Eulimidae). J. Mar. Biol. Assoc. UK, 64: 503-512 (1984).

Smith, A. B., M. Reich, and S. Zamora. Comment on supposed holothurian body fossils from the middle Ordovician of Wales (Botting and Muir, Palaeontologia lectronica: 15.1.9A). Palaeontol. Electron., 16(1): 488-492 (2013).

Sui, X. L. Aquaculture of sea cucumber. Beijing: China Agriculture Press (1990).

Sui, X., and H. Deng. Diseases and prevention of Apostichopus japonicus in Ponds. Fish. Sci., 23(6): 22-23 (2004) (in Chinese with English abstract).

Toral-Granda, V., A. Lovatelli, and M. Vasconcellos. Sea cucumbers: A global review of fisheries and trade. Rome: Food and Agriculture Organization of the United Nations (2008).

Tseng, C. K. On sea ranching in the Exclusive Economic Zone of China. Beijing: Ocean Publishing House (1979) (in Chinese).

Uthicke, S., and D. W. Klumpp. Microphytobenthos community production at a near-shore coral reef: seasonal variation and response to ammonium recycled by holothurians. Mar. Ecol. Prog. Ser., 169: 1-11 (1998).

Uthicke, S., and R. Karez. Sediment patch selectivity in tropical sea cucumbers (Holothuroidea: Aspidochirotida) analysed with multiple choice experiments. J. Exp. Mar. Biol. Ecol., 236: 69-87 (1999).

Uthicke, S., and J. A. H. Benzie. Effect of bêche-de-mer fishing on densities and size structure of Holothuria nobilis (Echinodermata : Holothuroidea) populations on the Great Barrier Reef. Coral Reefs, 19: 271-276 (2001).

Uthicke, S. Overfishing of holothurians: lessons from the Great Barrier Reef. FAO Fish. Tech. Paper, 463: 163-171 (2004).

Uthicke, S., and S. Purcell. Preservation of genetic diversity in restocking of the sea cucumber Holothuria scabra investigated by allozyme electrophoresis. Canadian J. Fish. Aquat. Sci., 61: 519-528 (2004).

Uthicke, S., D. Welch, and J. A. H. Benzie. Slow growth and lack of recovery in overfished holothurians on the Great Barrier Reef: Evidence from DNA fingerprints and repeated large scale surveys. Conserv. Biol., 18: 1395-1404 (2004). 
Utter, F. Genetic problems of hatchery-reared progeny released into the wild, and how to deal with them. Bull. Mar. Sci., 62 (2): 623-640 (1998).

Wang, B. H., W. B. Li, Y. Z. Li, and Y. H. Qu. World sea cucumber fishery. Shandong Fish., 15(4): 45-46 (1998) (in Chinese).

Wang, Y. G., X. J. Rong, C. Y. Zhang, and H. L. Sui. Primary problems in the culture of Apostichopus japonicus Selenka and techniques of disease prevention. Shandong Fish., 21 (10): 29-31(2004) (in Chinese).

Wang, Y. G., X. J. Rong, C. Y. Zhang, and S. F. Sun. Main diseases of cultured Apostichopus japonicus: prevention and treatment. Mar. Sci., 29(3): 1-7 (2005a) (in Chinese with English Abstract).

Wang, Y. G., C. Y. Zhang, X. J. Rong, J. J. Chen, and C. Y. Shi. Diseases of cultured sea cucumber, Apostichopus japonicus, in China. FAO Fish., 297-302 (2005b).

Wang, Y. G., S. F. Sun, and X. J. Rong. Stomach ulcer disease in auricularia of sea cucumber (Apostichopus japonicus) and its etiological identification. J. Fish. Sci. China, 13: 908-916 (2006a).

Wang, Y. G., B. Fang, C. Y. Zhang, and X. J. Rong. Etiology of skin ulcer syndrome in cultured juveniles of Apostichopus japonicus and analysis of reservoir of the pathogens. J. Fish. Sci. China, 13 (4): 610-616 (2006b) (in Chinese with English abstract).

Wang, P. H., Y. Q. Chang, J. H. Yu, C. Y. Li, and G. R. Xu. Acute peristome edema disease in juvenile and adult sea cucumbers Apostichopus japonicus (Selenka) reared in North China. J. Invertebr. Pathol., 96: 11-17 (2007).

Wang, J. Q., X. N. Sui, G. M. Gu, and W. H. Cong. Effects of combination of various feeds and feeding rates on growth and survival of juvenile sea cucumber Apostichopus japonicus. Fish. Sci. (Dalian), 27(2): 55-58 (2008).

Wang, C. Preliminary studies on the harmful effects and mechanisms of Ulva prolifera Green Tide. Qingdao: Institute of Oceanology, Chinese Academy of Sciences (2010) (in Chinese with English abstract).

Wu, Y. Q., Y. H. Cui, D. Y. Sun, B. L. Zhang, and J. H. Li. Study on enhancement release of Apostichopus japonicus in shallow sea rocky area of Lingshandao. Shandong Fish., 13(1): 22-24 (1996) (in Chinese).

Xie, Z. M. Aquaculture and restocking technology for sea cucumbers and urchins. Beijing: Jindun Publishing House (2004) (in Chinese).

Xing, X. Z., and Q. Z. Wang. Discussion of development and technologies on sea cucumber aquaculture. Mar. Fish., 3: 123-125 (2000) (in Chinese with English abstract).

Xue, Q. R. Aquaculture technology status and existing problems of sea cucumber in China. Shandong Fish., 24(11): 1416 (2007) (in Chinese).

Yang, H. S., J. Wang, Y. Zhou, T. Zhang, P. Wang, Y. C. He, and F. S. Zhang. Comparison of efficiencies of different culture systems in the shallow sea along Yantai. J. Fish. China, 24(2): 140-145 (2000) (in Chinese with English abstract).

Yang, H. S., X. T. Yuan, Y. Zhou, Y. Z. Mao, T. Zhang, and Y. Liu. Effects of body size and water temperature on food consumption and growth in the sea cucumber
Apostichopus japonicus (Selenka) with special reference to aestivation. Aquac. Res., 36: 1085-1092 (2005).

Yao, X. M., H. Y. Wang, S. L. Xing, and X.Y. He. The effects of temperature and water quality on feeding and growth of Holothuria scabra. Fish. Sci. Liaoning, 26: 292-295 (2007) (in Chinese with English abstract).

Yingst, J. Y. The utilization of organic matter in shallow marine sediments by an epibenthic deposit-feeding holothhrian. J. Exp. Mar. Biol. Ecol., 23: 55-69 (1976).

Yokoyama, H. Growth and food source of the sea cucumber Apostichopus japonicus cultured below fish cages-Potential for integrated multi-trophic aquaculture. Aquaculture, 372-373: 28-38 (2013).

Yu, C. Q., W. Kao, S. D. Li, and X. J. Gu. Research on pond aquaculture for sea cucumber. Fish. Sci., 17(6): 15-18 (1998) (in Chinese).

Yu, D. X., H. L. Sun, S. Q. Chen, Y. Zhang, C. L. Liu, and J. Tan. Healthy Aquaculture Technology of Sea cucumber (second edition). Beijing: Ocean Press (2010) (in Chinese).

Yu, Z. H., C. Q. Hu, Z. H. Qi, H. Y. Jiang, C. H. Ren, and P. Luo. Co-culture of sea cucumber Holothuria leucospilota with the Pacific white shrimp Litopenaeus vannamei. J. Fish. China, 36(7): 1081-1087 (2012) (in Chinese with English abstract).

Yu, Z. Y. The raft culture technology of sea cucumber Apostichopus japonicas in the southern China. J. Aquac., 5: 7-8 (2013) (in Chinese).

Yuan, X. T., H. S. Yang, Y. Zhou, Y. Z. Mao, Q. Xu, and L. L. Wang. Bioremediation potential of Apostichopus japonicus ( Selenka) in coastal bivalve suspension aquaculture system. Chinese J. Appl. Ecol., 19(4): 866-872 (2008) (in Chinese with English abstract).

Yuan, X. T., H. S. Yang, L. L. Wang, Y. Zhou, H. R. Gabr. Effects of salinity on energy budget in pond-cultured sea cucumber Apostichopus japonicus (Selenka) (Echinodermata: Holothuroidea). Aquaculture, 306: 348-351 (2010).

Zhang, B. L., D. Y. Sun, and Y. Q. Wu. Preliminary analysis on the feeding habit of Apostichopus japonicus in the rocky coast waters off Lingshan Island. Mar. Sci., 3: 11-13 (1995) (in Chinese with English abstract).

Zhang, L. Q., and Y. H. Liu. Aquaculture techniques of sea cucumber and sea urchin. Qingdao: The Press of Ocean University of Qingdao (1998) (in Chinese).

Zhang, C. Y., Y. G. Wang, and X. J. Rong. Isolation and identification of causative pathogen for skin ulcerative syndrome in Apostichopus japonicus. J. Fish. China, 30(1): 118-123 (2006) (in Chinese with English abstract).

Zhang, C. Y., G. F. Chen, Z. Xu, P. S. Yan, and Y. G. Wang. Advances in Diseases of Sea cucumber Apostichopus japonicus-A review. Fish. Sci., 30(10): 644-648 (2011) (in Chinese with English abstract).

Zhou, Y., H. S. Yang, T. Zhang, S. L. Liu, S. M. Zhang, Q. Liu, J. H. Xiang, and F. S. Zhang. Influence of filtering and biodeposition by the cultured scallop Chlamys farreri on benthicpelagic coupling in a eutrophic bay in China. Mar. Ecol. Prog. Ser., 317: 127-141 (2006). 